\title{
Conservación, devoción, documentación. Vírgenes con Niño medievales de la provincia de Soria
}

\author{
Proyecto Cultural Soria Románica*, Fundación Duques de Soria \\ Francisca Diestro Ortega y Josemi Lorenzo Arribas
}

\begin{abstract}
Resumen: La conservación de cinco imágenes de Vírgenes con Niño de la provincia de Soria nos ha obligado a reflexionar sobre aspectos que van más allá de la pura materialidad de la pieza y que, no obstante, han de condicionar dicha labor de intervención. Uno de ellos es el uso que la talla va a tener una vez intervenida. Si conserva una devoción activa, su tratamiento habrá de ser distinto de si su fin va a ser expositivo, como mera pieza de interés artístico. Otro es la necesidad de consultar y utilizar la documentación escrita conservada en los archivos como parte del propio proceso.
\end{abstract}

Palabras Clave: Virgen con Niño, Románico, gusto popular, conservación, Soria

Resumo: A conservação de cinco imagens da Virgem com o Menino da província de Sória, obrigaram-nos a reflectir sobre aspectos que vão para além da pura materialidade das peças e que, no entanto, irão condicionar o próprio trabalho de intervenção. Um deles refere-se à função que a talha irá ter, uma vez intervencionada. Se conservar um culto activo, o tratamento terá que ser distinto do que se o seu fim tiver um carácter expositivo, como mera peça de interesse artístico. Outro aspecto é a necessidade de consultar e utilizar a documentação escrita conservada nos arquivos como parte do próprio processo.

Palavras-chave: Virgem com o Menino, Românico, gosto popular, conservação, Sória.

Abstract: This paper surveys the conservation of five sculptures of Virgins and Child belonging to the province of Soria (Spain). Some important aspects which determine the methodology adopted have to be considered. One of them is the later use of the sculpture. The conservation will be carried out differently if the image acts as an active support of devotion or if its purpose is solely to be exhibited as a work of art. Attention is paid on the need to check and to use archival documentation as part of the conservating process.

Key Words: Virgin with Child, Romanesque, Folk Taste, Conservation, Soria

Estava la imagen en su trono posada, so Fijo en sus brazos, cosa es costumnada (...) Tenié rica corona como rica reína, de suso rica impla en logar de cortina, era bien entallada e de lavor muy fina, valié más essi pueblo qe la avié vezina

(Berceo, Milagros de Nuestra Señora, B. Dutton, ed., cc. 319-320)

1. Cuando sobre la mesa de proyectos a realizar, o en el taller, nos enfrentamos a la restauración de una talla como las que se pueden ver a continuación. ¿Qué hacemos, qué criterios debemos seguir? Desvestida de sus ropajes, se presenta una pieza que muestra a las claras su dilatada biografía y la huella que el paso del tiempo ha dejado impresa en la talla. En este momento, a quien tiene que tomar la decisión de intervenir se le abre un abanico de posibilidades tan grande como complejo. 
Pretendemos, con esta reflexión, continuar la que hacíamos en el anterior número de esta misma Revista (Esteras y Lorenzo 2009), pues ambas tratan de las complejas relaciones entre gusto popular y criterios de actuación actuales, aspectos que no suelen formar parte de las agendas actuales de intervención. [Figura 1]

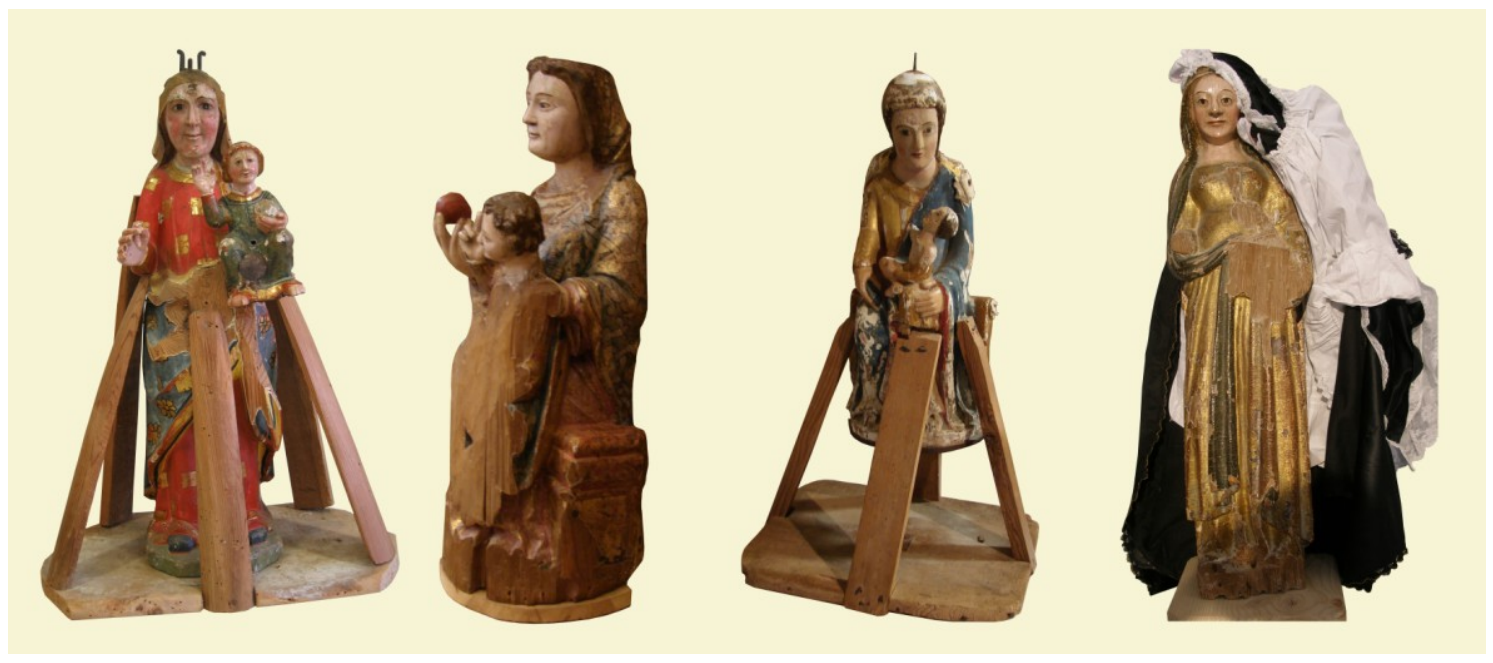

Figura 1. Vírgenes con Niño. De izquierda a derecha: Cubo de la Sierra, Villálvaro (del Rosario), San Andrés de Soria, y Miño de San Esteban, con diferentes alteraciones en sus volúmenes, acabados y significados devocionales

2. Las cuatro imágenes de la Figura 1 son casos frecuentes, cosa es costumnada que diría Berceo, y no suponen ninguna excepcionalidad (la quinta, al ser pétrea, supone un caso distinto). La Virgen de Cubo de la Sierra es una talla en madera con la Virgen de pie y Niño adosado, propia de una estética protogótica, que posteriormente se repolicromó ${ }^{1}$ y se le añadió una corona, con el consiguiente tornillo para fijarla; finalmente acaba como imagen vestidera quizá en el transcurso del siglo XVIII, con la adición de la consabida estructura que diera vuelo a los ropajes, para lo que se hace necesario modificar la posición del Niño, que se arrancó y se volvió a vincular con la madre a través de un grosero clavo de forja. En su momento, la estructura vestidera se perforó para incrustarle un aspa metálica que se fijaba a las andas, operación necesaria para poderla procesionar. A la Virgen del Rosario (Villálvaro) no fue necesario adicionarle soporte externo, y bastó con fracturar con hacha toda su parte frontal y adosarle en su base una discreta plancha de madera para fijarla a las andas. Un caso parecido al primero es el de la Virgen de San Andrés de Soria, si bien el menor tamaño de la imagen obligó a dejarla literalmente suspendida sobre la estructura. Finalmente, la Virgen de Miño de San Esteban, con tosca peana de nuestros días, fue más alterada que las otras: la amputación completa del Niño y su consiguiente pérdida. De Virgen con Niño a Virgen huérfana, sin Él, ése fue el alto precio de la supervivencia, de las adaptaciones a las nuevas prácticas devocionales que fueron llegando en su día. Quizá fuera en este momento cuando la talla adquiere el aspecto con que la podemos contemplar hoy, como Virgen Dolorosa, aunque la documentación parroquial no dice nada sobre este particular y sólo se puede apuntar como hipótesis.

3. Estos ejemplos nos muestran, una vez más, cómo la transformación de la talla original (por motivos devocionales u otros) ha sido la eficaz fórmula que ha garantizado su supervivencia (Villar Movellán 1989). Se han conservado porque se han alterado. De no haberse sabido adaptar la talla, por muy traumáticos que hayan podido ser los cambios, estas figuras de madera hubieran terminado sus días enterradas, destruidas, y sustituidas por otras más modernas. Pero no ha sido un afán de reciclar y mantener a ultranza la materialidad de la pieza lo que ha propiciado estos procesos. Más bien, dos factores se nos antojan fundamentales: el principal, la devoción; secundario, pero importante, la falta de medios económicos para sustituir una imagen por otra realizada ex novo. Lo 
cierto es que el respeto a las tallas marianas, y la devoción a esa talla y no a otra (no por tanto una cuestión ya de meras advocaciones) ha garantizado la supervivencia de tan gran cantidad de imágenes medievales, justificando sus periódicas repolicromías y la adición de los atributos o adornos de turno, que modificaban la apariencia externa, pero mantenían lo que se consideraba esencial: el alma de la talla, el pedazo de madera que, por metonimia, llegó a ser la propia imagen de la Virgen, única e irremplazable. Volviendo a los versos berceanos que abren estas líneas, valié más essi pueblo qe la avié vezina. Ya en la Edad Media, la devota feligresía era consciente del valor que otorgaba poseer una talla bien dispuesta. Significativamente, en castellano se emplea el verbo encarnar para referirse a policromar con el color de la carne los extremos de una pieza que representan partes que quedan visibles del cuerpo humano. La metáfora es poderosa, y al encarnar se está insuflando vida a un pedazo de madera. Así, ésta no representaba a la Virgen: era la Virgen, en una lucha secular ortodoxia/heterodoxia, religiosidad dirigida/devoción popular, que se ha mantenido hasta nuestros días, con el problema de fondo latente de la iconodulia.

4. Traemos a estas páginas unas reflexiones motivadas por el trabajo diario con bienes muebles que obligan a replantearnos continuamente los presupuestos teóricos de los que parte la labor conservadora, con el fin de afinar criterios e introducir, en su caso, aspectos a tener en cuenta cuando se interviene una pieza así, contraponiendo la enunciación paradójica de ser simultáneamente bien mueble (con valor histórico-cultural, estético, inerte, donde prima lo que se ve, el continente) y cuerpo vivo (con valor devocional, influyente, privilegiando el contenido, lo que no se ve, a lo que dicho cuerpo remite $)^{2}$.

5. El soporte material que motivan estas líneas se compone de cinco imágenes que han sido objeto de estudio, conservación y restauración en el marco del Proyecto Cultural Soria Románica, conjunto que guarda bastante coherencia iconográfica (Vírgenes con Niño), estilística (protogóticas/góticas), tópica (Sur de la provincia de Soria, salvo Tajahuerce) y cronológica (ss. XIII-XV). Además, otros hechos de su devenir las agrupan por afinidad, como el hecho de su ubicación en templos con categoría de ermitas desde hace varios siglos, con sólo una excepción (de nuevo Tajahuerce) ${ }^{3}$, la típica superposición de repolicromías en su superficie, la conservación de sus advocaciones populares, y la vigencia devocional de tales imágenes en la actualidad. Esta coherencia interna nos permite agruparlas de cara a las reflexiones que se han de seguir.

6. Se trata de las imágenes advocadas como Virgen de Lagunas (Villálvaro), de las Alcubillas (Alcozar), del Val (Pedro), de la Asunción (Tajahuerce), y del Barrio (Rioseco de Soria). Estas Vírgenes, hoy intervenidas, no han sido hasta el momento objeto de interés por parte de la bibliografía especializada en bienes muebles. Rompe esta atonía una referencia de pasada a la Virgen del Val (Pedro), en un artículo de 1958 en que Teógenes Ortego descubre el valor de la ermita y se refiere de pasada a la talla ("modesta imagen sedente del siglo XIV, torpemente repintada en época moderna") (Ortego 1958:226), y otras dos escuetas citas valorativas a dos de ellas (Alcozar y Tajahuerce) en un trabajo de hace un cuarto de siglo, de donde entresacamos las siguientes afirmaciones:

- Virgen de Alcozar (Alcubillas): "Policromía: burda y poco acertada, del siglo pasado [siglo XIX] (...) Cronología: siglo XIII".

- Virgen de la Asunción (Tajahuerce): "Cronología: fines del XII, principios del XIII (...) Como anécdota diremos que gran impedimento nos pusieron para poder fotografiar y ver dicha imagen" (Hernández Álvaro 1984:74 y 109).

7. En la reciente exposición Las Edades del Hombre, celebrada en la Concatedral de San Pedro de Soria en el año 2009, se expusieron dos de estas imágenes: la de Tajahuerce, y la de Rioseco de Soria, que ha servido para que al menos esta segunda se haya podido estudiar en profundidad con los datos disponibles (Diestro Ortega 2009: 395-397; Hernández Álvaro 2009: 392-394)4. No nos consta que haya bibliografía alguna de la Virgen de Lagunas. 
8. En líneas generales, consideramos que es muy difícil fechar ninguna de estas imágenes en el siglo XII, y dudoso en el XIII. Sabida es la tendencia a anticipar las cronologías de las piezas con valor artístico en la errónea creencia de que así se le otorga más valor a la misma. En este vicio incurre tanto la bibliografía local, escasa en este caso, como la más general, que muchas veces da por buenas ciertas afirmaciones sin mayor consideración crítica. A partir exclusivamente de cánones estilísticos, cuando menos responden estas Vírgenes con Niño al momento protogótico, siendo la de Rioseco posterior. Cosa bien distinta, y muy arriesgada, al menos para el caso soriano, es determinar cuándo tiene lugar ese momento. La experiencia de trabajo diario con el Románico de la región nos hace sospechar que la sintaxis románica se mantiene en el Oriente de Castilla, en algunos puntos, hasta bien entrado el siglo XIV, como bien intuyó Ortego con respecto a la Virgen del Val 5 . Con pocas novedades estructurales, funcionaron las soluciones que este estilo aportó durante un tiempo que la Historia del Arte hace ya plenamente gótico. El Gótico llegó, pero también con un acusado desfase temporal con respecto a lo que se considera canónico (se documentan obras arquitectónicas de estilo gótico en la primera mitad del siglo XVIII, como por ejemplo la cabecera de la iglesia de San Miguel, en Andaluz). Así pues, tampoco nos parece que calificarlas de un modo u otro sea un asunto que condicione de manera efectiva el estudio y análisis real de la pieza ni que afecte en absoluto a su proceso de conservación-restauración.

9. Entendemos el proceso de intervención como un continuum integral conducente a asegurar la mejor interpretación y conservación de la pieza. Para ello, hay que procurar obtener la máxima información del bien a conservar. En su pura materialidad, la atenta observación y análisis de la misma en todas sus partes y en conjunto, se muestra un proceso imprescindible. Luego, la toma de muestras, los procesos analíticos correspondientes y las ulteriores catas en las partes más adecuadas, en función de los pasos previos, suele ser el paso subsiguiente. Pero hay una información que no está en la talla, que no tiene tangibilidad y que no siempre se tiene en cuenta. Es más, frecuentemente o se considera prescindible o no llega a plantearse. De un lado, esa cultura inmaterial que rodea a una imagen de estas características (devoción, tradiciones asociadas, leyendas vinculadas...). De otro, la documentación escrita que dicha talla haya generado.

\section{Documentación y conservación: la necesidad de informarnos}

10. La documentación escrita, como parte de los trabajos previos a las tareas de conservaciónrestauración, se impone como una necesidad en el siglo XXI, por más que luego la realidad lleve otros caminos y la necesidad del concurso de otros oficios y profesionales, y los menguados presupuestos, unido, claro, a que no es una exigencia por parte de la Administración, haga que pocas veces se tengan a mano los datos escritos de las transformaciones de una pieza cuando se va a intervenir en ella. Es más, a veces están publicados, pero no se consultan porque no se sabe o, lo que quizá es peor, porque no se consideran relevantes de cara a la intervención.

11. Fundamentalmente, son dos las fuentes que nos valen para documentar bienes muebles asociados al uso eclesiástico: los libros de protocolos notariales, por lo general agrupados en los respectivos Archivos Históricos Provinciales (también en Ayuntamientos o archivos ad hoc), y los libros de fábrica o los de cofradías, custodiados en las propias parroquias o, modernamente, en los Archivos Diocesanos. Ni unos ni otros informan de la hechura de las imágenes medievales por una cuestión puramente cronológica (los más antiguos raramente anteceden la época de los Reyes Católicos). Los protocolos notariales recogen, como su nombre indica, los acuerdos entre partes elevados a escritura pública, de que dan fe los notarios correspondientes. Para los fines que nos interesan, los contratos entre promotor y realizador de un retablo o una talla, por ejemplo, ofrecen una riquísima información para conocer el punto de partida de una obra, los pleitos entre partes por desacuerdo de una de ellas etc. Los Libros de Fábrica dan cuenta más sucinta, de hechuras y distintos aderezos, singularmente decorativos: policromías, repintes, estofados, encarnaciones, sin que falten detalles de mayor envergadura (reposición de manos y dedos, o inclusión de ojos de cristal en el siglo XVIII). La mayor parte de la documentación, cuando la hay, informa del estado de 
alhajas y vestuario de las imágenes, información importante para dar cuenta del uso que la imagen ha tenido en cada momento y su mayor o menor éxito devocional. Otras veces, se alude directamente a este hecho cuando se habla de una rogativa por causas coyunturales que aconsejaron procesionarla (una sequía prolongada, por ejemplo).

12. A la imagen de la Virgen del Rosario de Villálvaro, advocación muy venerada desde finales del siglo XVI en la España contrarreformista, que hemos visto ya al comienzo de estas páginas, también se refiere un asiento inserto en un Inventario de bienes de ese mismo siglo:

"Unas dos coronicas de plata, la una para la imagen de Nuestra Señora, que está en el altar mayor y la otra para el Niño Jesús, las cuales dio el bachiller Cearreta, cura de la dicha villa en fin de noviembre de [15]77 años".

13. Explícitamente se cita su advocación en otro documento, de principios del siglo XVII, congruente con la extensión que alcanzó después de la batalla de Lepanto (1571), en que se propaló la pretendida mediación del rezo del rosario como determinante para que los cristianos alcanzasen la victoria. Dice así el documento:

"Dio en servicio de la gloriosa Virgen una corona de plata labrada blanca, para la Madre de Dios del Rosario y una corona para el Niño que la Virgen tiene en sus brazos, de manera que son dos coronas, una para Nuestra Señora del Rosario y otra para su Niño Jesús, con lo demás que arriba está declarado.

Todo lo cual ofreció la dicha señora doña Juana de Guevara y Avellaneda a honra y reverencia de la Madre de Dios y de su Unigénito Hijo delante del altar de Nuestra Señora del Rosario, estando presente el bachiller Cabrejas, cura de la dicha iglesia, y mucha gente de la dicha villa, y por verdad lo firmó el dicho cura y la señora doña Juana, día, mes y año ut supra.

Una corona de plata para Nuestra Señora del Rosario.

Otra para el Niño que tiene en sus brazos. Diolo la señora doña Juana de Guevara y Avellaneda el año de 1612 años, día de Nuestra Señora de la O.’’7.

14. Efectivamente, coronas, rostrillos, mantos... esas adiciones de la devoción popular, son las que más presencia documental tienen, seguida de los objetos vinculados a dichas tallas que más se usan y se estropean, y más necesidad hay de reparar, por tanto; singularmente los tornillos de las peanas de la Virgen, y las propias andas. Contra ellos, vendría después la reacción ilustrada, uno de cuyos representantes fue el erudito Antonio Ponz. Un siglo y medio después de la cita anterior, se quejaba:

\footnotetext{
"Quisiera que me dijere el devoto dotado de discreción y de prudencia cuánto tiempo se tardaría en condenar un escrito que descubriese a Nuestra Señora conforme yo he visto repetidas veces sus imágenes, con cotillas, escotes, pendientes, aderezos, collares, mucho encaje, y en fin con todos los atavíos de que hace pompa la profanidad y el lujo. Semejantes dijes no pertenecen a la Madre de Dios, ni en ellos consiste la majestad y modestia con que se ha de exponer a la veneración de los fieles. La Virgen no está así en el Cielo, ni en la tierra anduvo de este modo"s.
}

15. Pero, contrariamente a lo que se cree, no hay que esperar a finales del siglo XVIII para leer testimonios escandalizados por estos, a su juicio, excesos, y ya en fecha tan temprana como 1635 Bernardino de Villegas clamaba: 
"...visten a los santos de sus oratorios con tantos dijes y galas, que es cosa indecentísima; y a veces le da a un hombre gana de reír viendo las brujerías que ponen a los santos; y otras de llorar, mirando la indecencia con que los santos y santas son tratados. ¿Qué cosa más indecente que una imagen de Nuestra Señora con saya entera, ropa, copete, valona, arandela, gargantilla y cosas semejantes?"

16. Obviaba el asceta que todos esos arreos en la indumentaria era lo que el pueblo vulgar hubiera gustado poder lucir, de haber tenido posibles. Ya que no podían, al menos sublimaban esa ostentación contribuyendo a adornar a la talla mariana de su parroquia.

17. Por el contrario, también había cierta sensibilidad en la época dorada de las vírgenes vestideras para apreciar los volúmenes y el trabajo de las tallas "antiguas". Así, en los mandatos de la visita pastoral que en 1756 se realiza a la iglesia parroquial de San Miguel de Andaluz (Soria), dispone el visitador:

"y asimismo en el nicho del Santísimo Cristo de la Vera Cruz se haga otro retablito y una efigie de Su Majestad, enterrando la que hoy se halla colocada por ser sumamente indecente, y asimismo otro retablito en el altar de Nuestra Señora del Rosario, y una efigie de hermosura y devoción, poniendo la de hoy en la sacristía, desnuda por ser de talla y no de la mayor indecencia" 10.

18. Se arrincona en la sacristía porque no estaba tan mal para enterrarla y así deshacerse de ella, y además parecía bonita. Una cuestión de gusto personal, por tanto, pero es que de gusto estamos hablando, y a veces la decisión de qué hacer o dejar de hacer depende mucho del gusto del promotor de una obra, si no del propio conservador-restaurador. Una responsabilidad demasiado grande para que recaiga en una sola de las partes... Esta noticia la ponemos en relación con otras, que no se refieren a las imágenes intervenidas por el Proyecto Cultural Soria Románica, pero sí están vinculadas con las localidades adonde éstas pertenecen. El mobiliario que había tenido un fuerte componente devocional, pues, se entierra en sagrado (igual que las personas) cuando deja de tener uso, por respeto, y por ello periódicamente aparecen objetos cultuales en las excavaciones arqueológicas en el interior de los templos y en la documentación. Así, sabemos que en Pedro, además de la talla medieval de la Virgen del Val había otra talla mariana, en este caso en la parroquia homónima, de cronología desconocida, que se manda enterrar en el siglo XVIII:

"que se entierre una imagen de Nuestra Señora que está al lado de la Epístola sobre una mesa, y otra que hay detrás del retablo haciendo un hoyo profundo al lado del Evangelio"11.

19. Allí debe estar, junto a los difuntos de las generaciones pasadas. En Alcozar, la campaña de intervenciones arqueológicas de 2009 en la ermita del Vallejo nos deparó un hallazgo de estas características, una sorpresa, porque a pesar de la buena y abundante documentación escrita de la parroquia, no había ninguna referencia a tallas enterradas. No sólo aparecieron dos, que por el mal estado de conservación no se puede deducir a quiénes corresponde, aunque una bien pudiera tratarse de una talla mariana, sino que junto a ellas, vieron la luz, por primera vez desde que fueran soterradas, las tablas de un antiguo retablo del siglo XVI, todavía con restos visibles de buena policromía ${ }^{12}$.

20. Volvamos a Villálvaro. Aun en localidades pequeñas, la documentación sirve para poner nombre a los artistas que policromaron las tallas. Por su antigüedad, merece citarse la referencia a la Virgen de Lagunas, encontrada en uno de los libros de fábrica de principios del siglo XVI, en que se documenta explícitamente una repolicromía. Hemos de suponer que ya estaba policromada con anterioridad, aunque no hayan quedado restos de pintura anterior a esta capa: 
"Se le recibe en cuenta al dicho mayordomo 125 mrs. que dio en pago a Peñaranda, pintor, para ayuda de pintar la imagen de la iglesia de Lagunas"13. [Figura 2]

21. .No sólo conocemos por este asiento el nombre de un artista activo por esta zona en fecha tan temprana, sino que el precio acordado, puesto en relación con otras referencias económicas contemporáneas, permite imaginar el valor que se le otorgaba a ese trabajo, equivalente, en este caso, por ejemplo, al precio de una fanega de trigo ${ }^{14}$. Según avancen los trabajos documentales sobre fondos de otras localidades, se podrá ir estableciendo un mapa y una cronología de artistas, zonas donde trabajaron, desplazamientos... información de gran valor para la Historia del Arte.

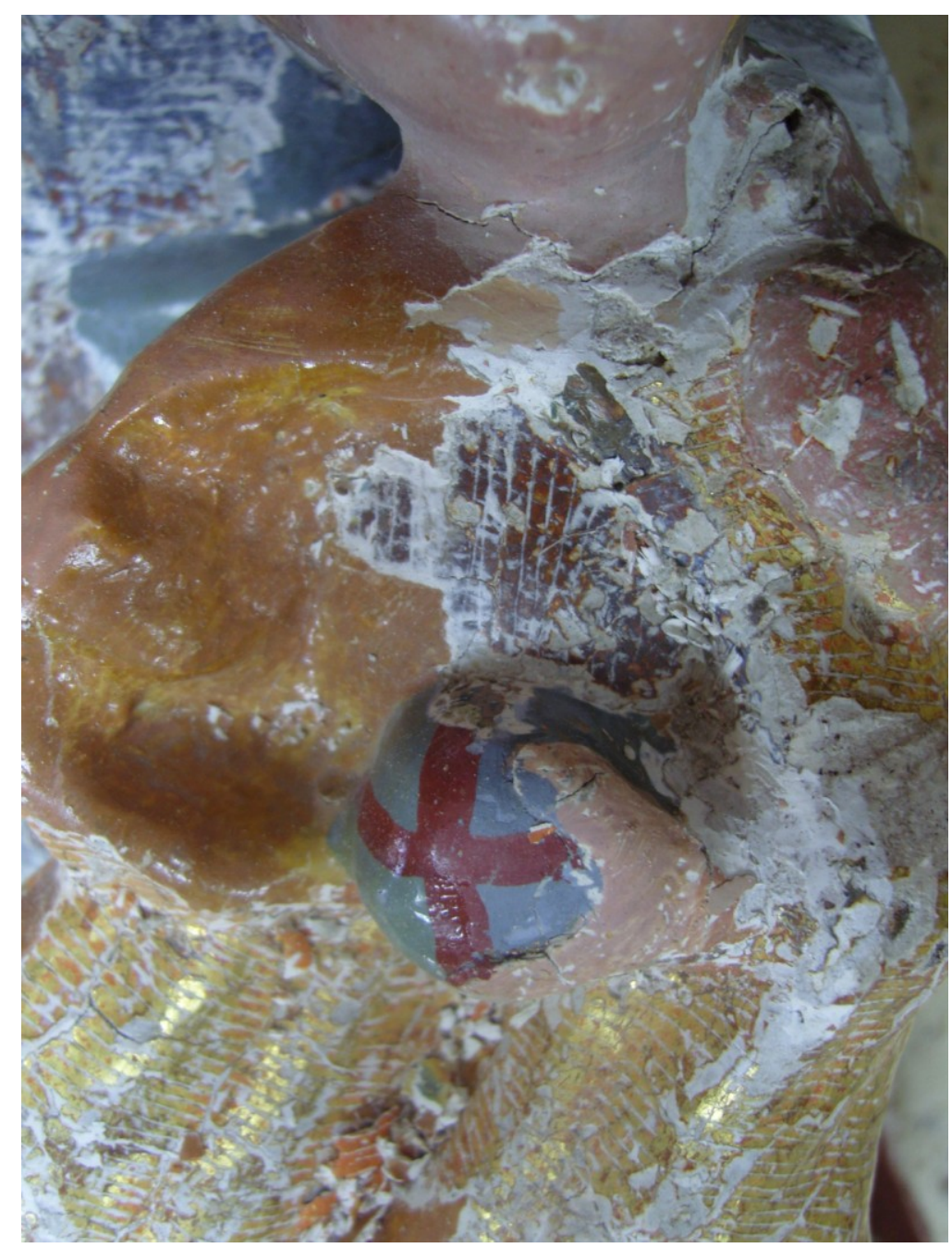

Figura 2. Superposición de policromías en la figura del Niño de la Virgen de Lagunas. La más antigua, un estofado de buena calidad, se corresponde con la obra del pintor Peñaranda, documentada en 1516

\section{Devoción y conservación}

22. Un elemento que consideramos que debe ser en algunos casos determinante de cara a plantear la conservación-restauración de un bien mueble es la devoción que hacia él, una talla en nuestro caso, muestre actualmente la población a la que pertenece. Si la pieza en cuestión ha dejado de tener vigencia devocional, o su destino va a vincularse a un museo o espacio expositivo, se puede plantear una intervención que compatibilice sus diversas capas de policromía y mostrando a través de su pura materialidad parte de la biografía de la pieza y sus diversos estilos. 
23. Otra cuestión bien distinta es cuando la pieza es venerada por la comunidad a la que pertenece. No se puede perder de vista que para dicha población, el principal bien es la talla en sí, entendida de una manera coherente y unitaria según el gusto popular (y la última repolicromía, acabado principal de una pieza, a veces condiciona la manera de verla decisivamente). En la provincia de Soria, como en tantos otros lugares de la geografía española, esta devoción mariana está muy arraigada. Buena muestra de ello fue la reciente ceremonia de la Coronación Canónica Pontificia de la Virgen del Rivero en San Esteban de Gormaz (Soria), el 1 de mayo de 2009¹5, devoción que entronca con el principal sentido que impulsó la hechura de estas imágenes en la Plena y Baja Edad Media ${ }^{16}$, cuando comenzó a ser reivindicado el papel de María frente a los anteriores modelos teológicos cristocéntricos.

24. En el proceso de actuación sobre las tallas que aquí tratamos, se ha procedido, por un lado, siguiendo los patrones y protocolos técnicos habituales ante los diagnósticos de daños igualmente comunes (presencia de insectos xilófagos, descohesión del soporte, fisuras por dilatación del mismo, pérdidas volumétricas localizadas y/o de algunos elementos menores, envejecimiento de adhesivos de origen natural, oxidación de barnices, oxidación de elementos metálicos añadidos que afectan al soporte, levantamientos y lagunas puntuales en policromía, acumulación de polvo y suciedad incrustada...), en los que no vamos a extendernos por sabidos. Sí nos interesa, como decíamos, centrarnos en esos otros aspectos que conviene tener en cuenta, y que exceden a veces la pura materialidad del objeto a intervenir.

25. El tratamiento de una pieza de estas características facilita el contacto con esa población que va a usufructuar la imagen, y se debiera aprovechar para recoger por escrito las leyendas o tradiciones asociadas a esa talla e incluirlas en la Memoria final de la intervención. Ese contacto con la gente permite además comenzar a explicar qué se va a hacer, el proceso a seguir, y el porqué, tema en que insistiremos más abajo. Por lo general, se tratará de versiones locales de tipos narrativos muy extendidos, y en las diferencias entre ellas suelen residir factores del máximo interés para la etnografía y la antropología. En nuestro caso, es singular el caso de la Virgen de Lagunas (Villálvaro). Recuerda la gente del pueblo cómo era normal que los zagales, descuidando su cometido, se reunieran para charlar o hacer de las suyas, dejando al ganado a su albur, relativamente controlado. En ocasiones, sacaban la imagen de la ermita para que, en su ausencia, fuera la Virgen quien asumiera el cometido de pastora, vigilando que los animales no entrasen a las zonas de cultivo. Bien, pues una vez, a la vuelta de los chavales, vieron éstos horrorizados cómo las ovejas estaban tranquilamente paciendo en la arada del cereal que ya despuntaba. En venganza por la incuria de la Virgen, hicieron un círculo en torno a ella, y la apedrearon... para que aprendiera para la próxima. Es decir, le aplicaron la misma fórmula que, más tarde, seguramente les tocaría sufrir a ellos en carne propia en forma de paliza, cuando se descubriera su falta de celo pastoril.

26. La devoción que se le tiene a esta talla, no obstante, ha provocado que llegara al día de hoy revestida de todos los elementos habituales (manto, túnica, rostrillo, coronas, otras alhajas, doble peana para fijarla a las andas procesionales...). No en vano, se la procesiona y se comparte entre los dos pueblos vecinos (Villálvaro y Zayas de Báscones) de los que equidista la hoy ermita (de Lagunas) de donde procedía la imagen.

27. Tras el estudio técnico previo y detallado de la talla, se determinó la existencia de tres niveles pictóricos, de carácter muy burdo el visible. Ese carácter de "cuerpo vivo" provocó que la última policromía con que hasta la intervención se mostraba la Virgen, sin duda realizada por la propia gente del pueblo, fuera una capa de color al temple con un espeso revestimiento de barniz totalmente oxidado, y que quedaba separada de los dos inmediatamente inferiores por otra gruesa capa de preparación blanca sobre tela que alteraba el volumen de la talla. Se valoró la eliminación de la capa exterior para acceder a la segunda, documentada tal como se ha dicho anteriormente. [Figura 3] 


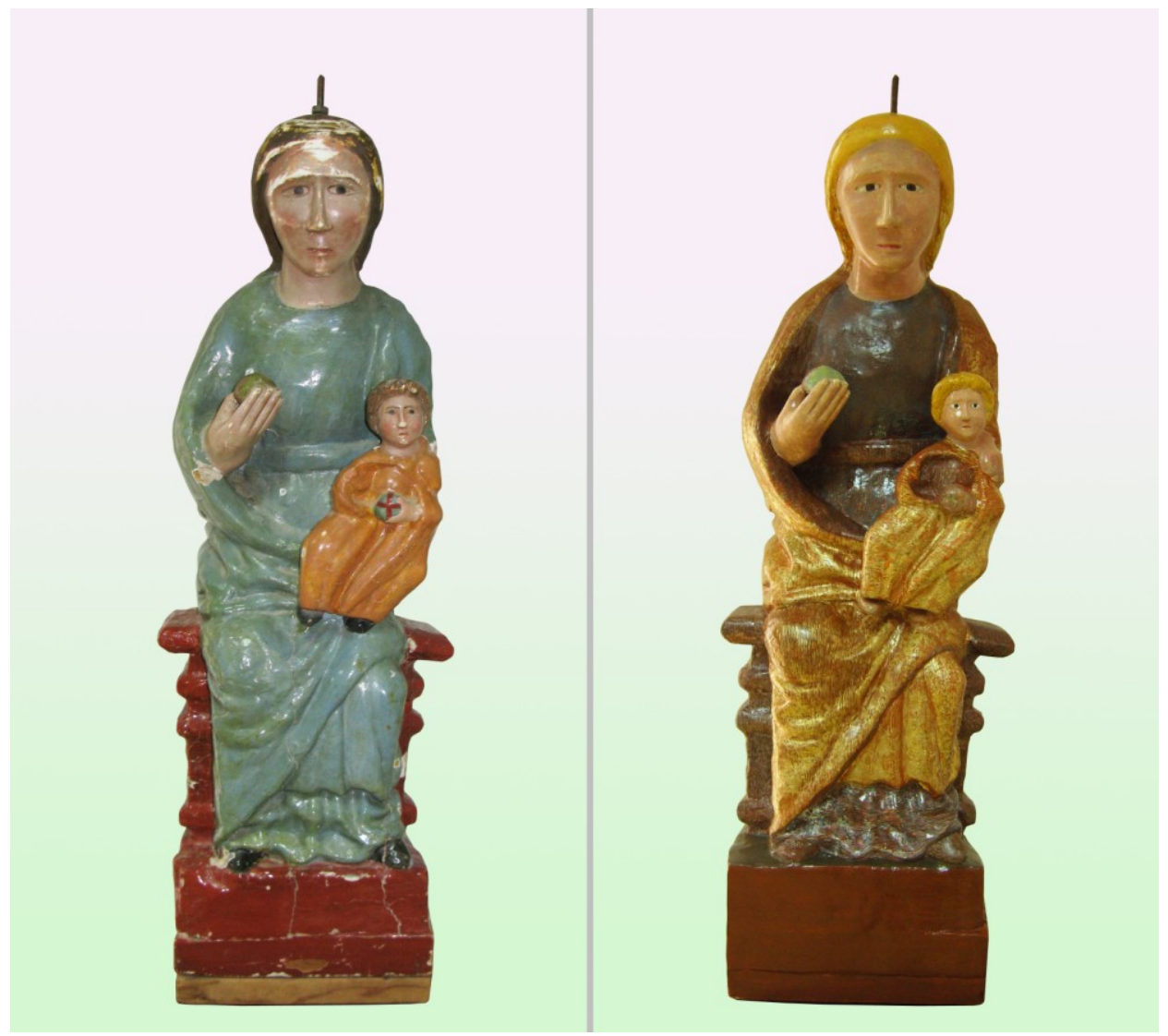

Figura 3. Virgen de Lagunas (Villálvaro), antes y después de la restauración realizada por el Proyecto Cultural Soria Románica (2009)

28. Uno de los "problemas" con que nos podemos encontrar es que una capa de policromía anterior que se pueda recuperar porque mejore la calidad artística de la talla según los criterios de conservación, la empeore según el juicio estético de quienes usufructúan la imagen. La Virgen de Lagunas, por ejemplo, ha pasado de tener un pelo de un color marronáceo indefinible, a ser una Virgen rubia, y estos pases metafóricos "por la pelu" de las figuras sagradas pueden llegar, efectivamente, a comentarse escandalosamente en la pelu real, en boca de las mujeres que tradicionalmente se han encargado de su cuidado y mantenimiento en la localidad. Son problemas complicados que no debemos soslayar. Con esto, obviamente, no defendemos que no haya que hacer nada por miedo a la reacción. Pero sí debemos preverla y actuar en consecuencia para asegurar las buenas relaciones posteriores tripartitas: la pieza, el trabajo que hemos realizado sobre ella, y la gente que la disfrutará, porque la falta de atención ante el uso devocional de una imagen puede invalidar un proceso de conservación volviendo ineficaz dicho proceso o, en caso extremo, la propia talla. En este punto hemos de constatar que los criterios empleados en la intervención siempre necesitan ser explicados (al contrario que en otros oficios), lo cual no implica que los receptores de la obra los vayan a entender, pero predispone de otra manera. Así, por ejemplo, acudiendo a nuestra experiencia, podemos relatar que tras actuar hace una década sobre un Cristo barroco procedente de Covaleda (Soria), una vez de vuelta al pueblo, no gustó, y se procedió expeditivamente. Fue vuelto a restaurar, por decirlo de algún modo. En ausencia del sacerdote, la cofradía que tenía a su cargo dicha talla, por iniciativa propia, ordenó una repolicromía de la misma, en tonos oscuros, encargándosela por su cuenta a un "restaurador" vinculado al pueblo porque pasaba allí la temporada de verano. Es otro aspecto a tener necesariamente en cuenta, porque los bienes muebles eclesiásticos muchas veces escapan al control de la propia Iglesia, y estas actuaciones se repiten una y otra vez. 
29. Volviendo a las prácticas populares en relación con las tallas devocionales, aunque las costumbres no siempre sean devotas, el lapidamiento no siempre respondía a una venganza, como en el caso anteriormente expuesto. Otra fue la causa que afectó a la Virgen de la Asunción (Tajahuerce). El lugar donde tradicionalmente se la ha venerado fue una hornacina abierta sobre el muro meridional del templo, encima de la portada románica. Se la protegió de las palomas con una tela metálica que paulatinamente se fue desprendiendo en su parte superior, lo que excitó la puntería de la chavalería del pueblo, según informan hoy los ancianos que hace décadas protagonizaban la acción agresiva, que a golpe de pedradas dejaron marca de sus aciertos en la citada imagen.

30. La Virgen del Val (Pedro) es otro caso de muestra devocional. Estuvo en su momento revestida, pero en la actualidad, por insistencia de los sacerdotes, se mostraba desde hace años sin ropajes, con el convencimiento de que así se acrecentaba el valor que de por sí tiene la talla desnuda, decisión no siempre aplaudida unánimemente por el pueblo, aunque consintió. [Figura 4]

31. En los análisis previos a la intervención, se descubrieron tres capas de policromía, la intermedia de notable calidad. Lo más curioso es que bajo las dos últimas aparecía parte de la figura quemada. Nuevamente, una talla se salvó del enterramiento o de su destrucción por la devoción que se la profesaba, pues aun con parte de su madera calcinada, la repolicromía sirvió para mantenerla vigente. Hoy, con una curiosa costumbre, el escaso vecindario de Pedro insiste en procesionarla una vez al año. Ese día veraniego, la Virgen sale de la parroquia, donde desde hace años se ubica por motivos de seguridad, y se acerca hasta la ermita (distantes una de otra poco más de cien metros), para, tras la ceremonia religiosa y lúdica, volver a su emplazamiento habitual, sin que llegue a residir tiempo alguno en la citada ermita, como hacía antaño. [Figura 5]

32. Una vez que la talla luce con su volumetría medieval, y ya intervenida, ¿habrá que recomendar que la vistan, una vez devuelta, como tradicionalmente se hacía? ¿No habrá de estar condicionada la intervención precisamente por ese resultado final? Parte de esos problemas quizá se paliaran si considerásemos que el proceso no acaba una vez que la pieza vuelve a su emplazamiento, sino cuando el/la conservador/a-restaurador/a, en conjunción con quien promueve la intervención, explica los valores de la misma y la actuación que, en consecuencia, se ha practicado. Los ropajes son parte inherente al valor devocional de la imagen, y en ocasiones, también cumplen una finalidad práctica. Nos encontramos con casos en que el pueblo (o el párroco) decide mantener solamente el manto y corona de una Virgen, por ejemplo, más que por motivos estrictamente cultuales, por razones estéticas, pues así se oculta la trasera de una talla que está vaciada, o que no recibió policromía... y facilitar la contemplación cuando se procesiona. Un aspecto, el de la difusión, que estimamos imprescindible, tanto de cara a la gente que tiene por suya la imagen, como de cara a la propia pieza, que así puede prever un futuro cercano sin alteraciones espontáneas. Si desde el principio se tiene en cuenta este hecho, cuando se proceda a hacer la encuesta oral entre el vecindario de la localidad a que pertenece la talla, a fin de conocer qué se dice y qué datos ofrece el saber popular, se puede devolver tal información explicando cómo se va a proceder, por qué se hace etc.

33. El caso de la Virgen de las Alcubillas (Alcozar) responde a otro manojo diferente de problemas. Uno viene motivado por la escasa devoción que, ya de antiguo, se la profesa, para lo que influye, sin duda, la presencia en el retablo mayor de la Virgen del Vallejo, que monopoliza la atención cultual mariana. Actualmente descansa en un retablo colateral de la parroquia, sin vestir. Apenas se recuerda su advocación y, de hecho, se desconoce su procedencia, datos significativos de por sí en el "barómetro" devocional. [Figura 6] 


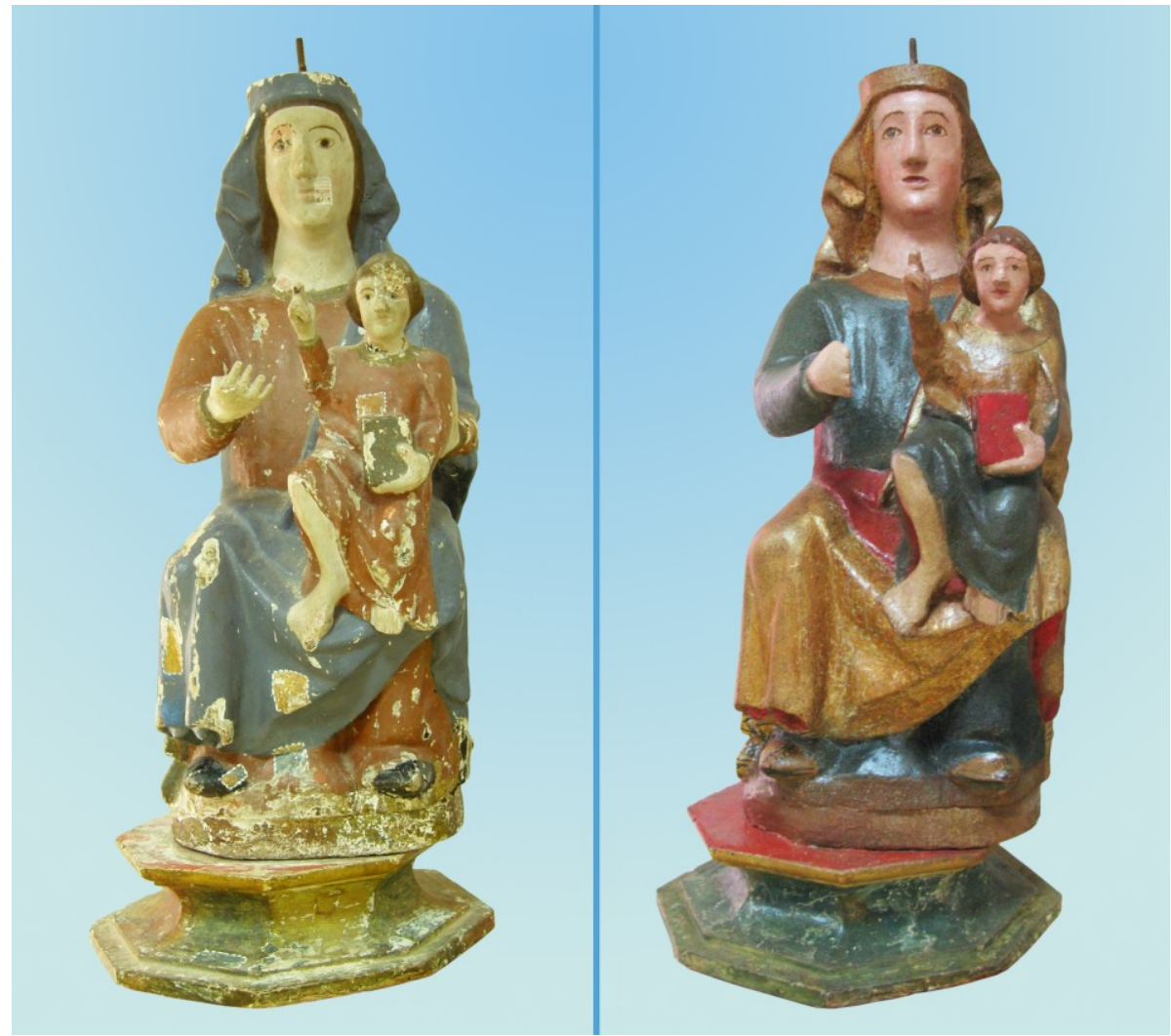

Figura 4. Virgen del Val (Pedro), antes y después de la restauración realizada por el Proyecto Cultural Soria Románica (2009)

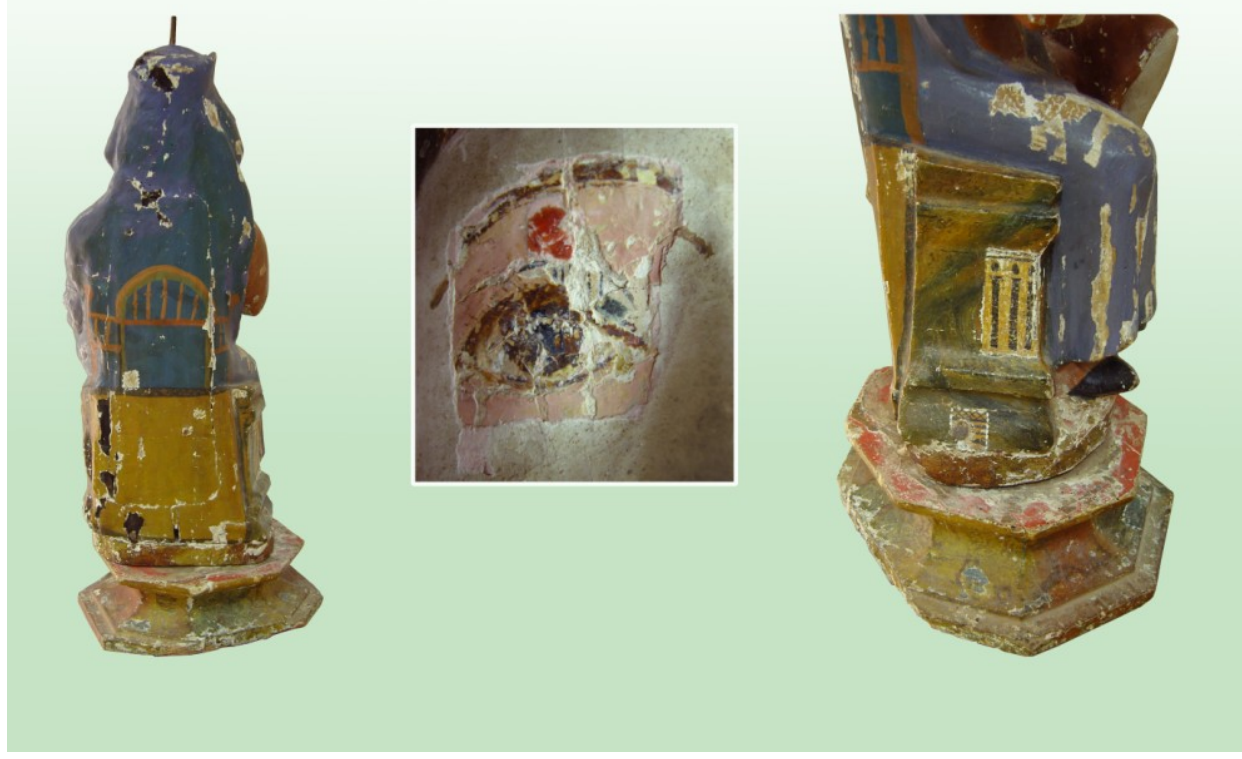

Figura 5. Catas en la Virgen del Val (Pedro), donde se observa la parte quemada subyacente en la primera imagen, a la izquierda del sitial, así como la última y popular repolicromía, y las anteriores, en las catas en el ojo y el sitial 


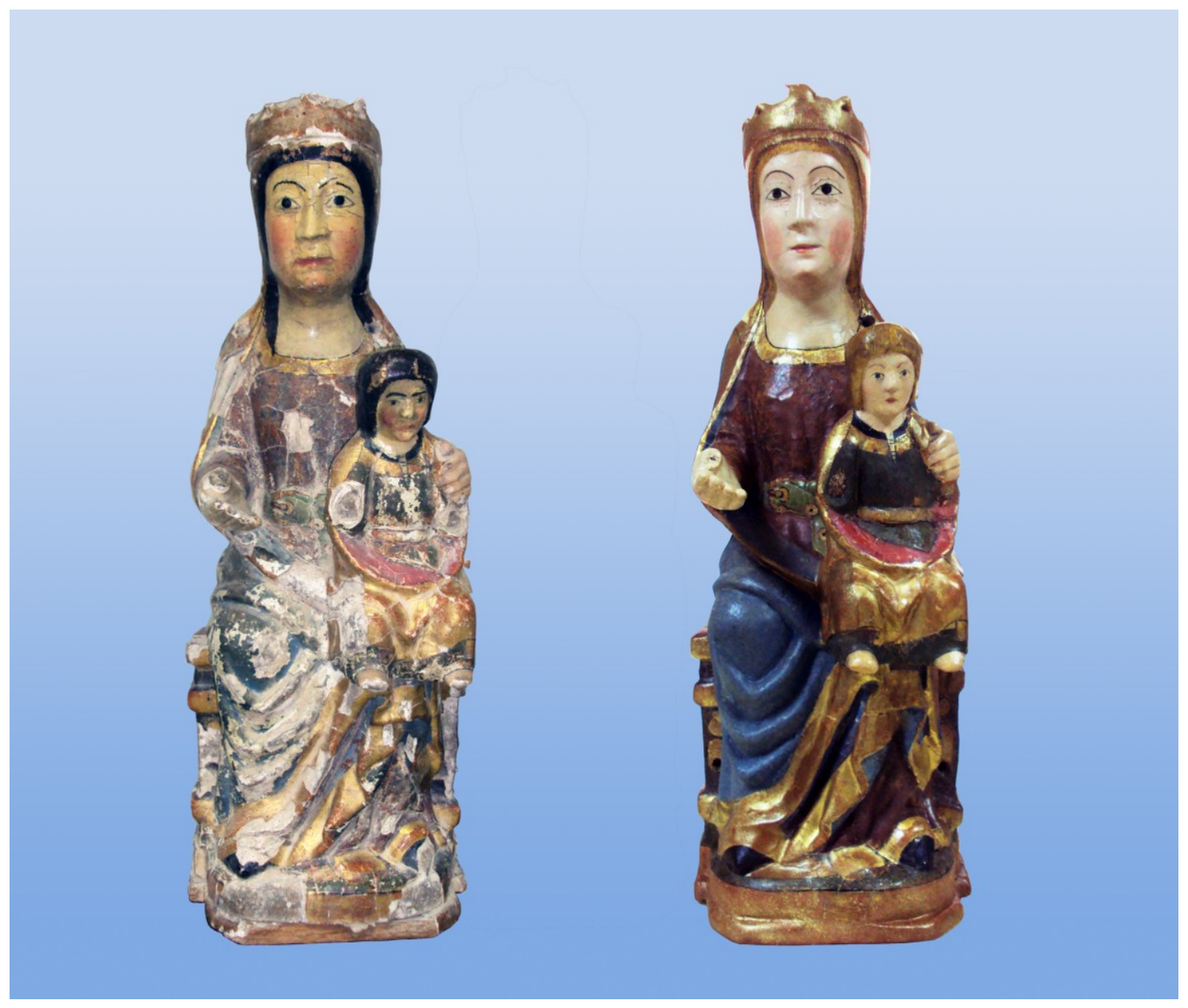

Figura 6. Virgen de las Alcubillas (Alcozar), antes y después de la restauración realizada por el Proyecto Cultural Soria Románica (2010)

34. Durante el proceso de intervención que se ha llevado a cabo se ha podido constatar la existencia de una gruesa capa de preparación que al envejecer se ha quebrado de tal forma que ha provocado rígidos levantamientos y abundantes fisuras, desfigurando además detalles volumétricos como es el caso de la nariz del Niño. Esta capa sirvió de base a una decoración polícroma de gran calidad y buena factura, con suaves pinceladas de técnica más similar a un tratamiento pictórico y dibujístico que al escultórico (como los detalles en cinturón y perfiles negros en los pliegues de la túnica en la zona inferior). No se trata de la primera policromía, de la que no queda resto alguno, y esta repolicromía es la que se ha decidido mostrar después de la intervención. También a este momento corresponde el retallado en la corona de madera de la Virgen. [Figura 7]

35. Un detalle curioso, con el que no nos habíamos encontrado hasta la fecha, corresponde al remarque en los ojos de la Virgen, finas líneas discontinuas que marcan sus cuencas. Quizá responda al momento en que se plantearon insertarle unos ojos vidriados (a la moda del siglo XVIII) y, cual cirujano, siluetearon la zona a vaciar. Por lo que fuera, la obra no se llegó a realizar y con posterioridad una nueva capa de policromía unificó las carnaciones de la cara y el cabello, ocultando las intenciones reformadoras. No es improbable que la imagen fuera vestidera en el momento en que la encarnan, ya que sólo se pinta la zona visible, dejando el resto con la policromía previa. [Figura 8] 


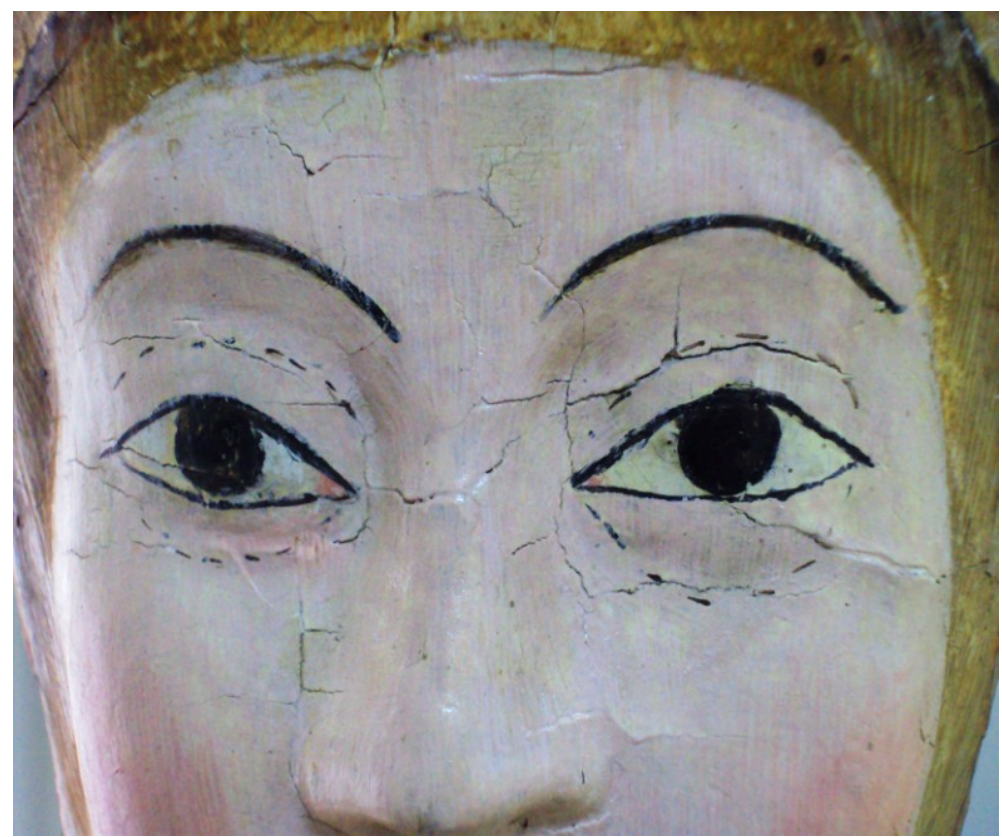

Figura 7. ¿Perfilado de la superficie a vaciar para insertar ojos de cristal a la Virgen de las Alcubillas (Alcozar)? Corresponde a la capa pictórica inmediatamente inferior a la que tenía hasta la intervención, que es la que conservaba el resto de la talla

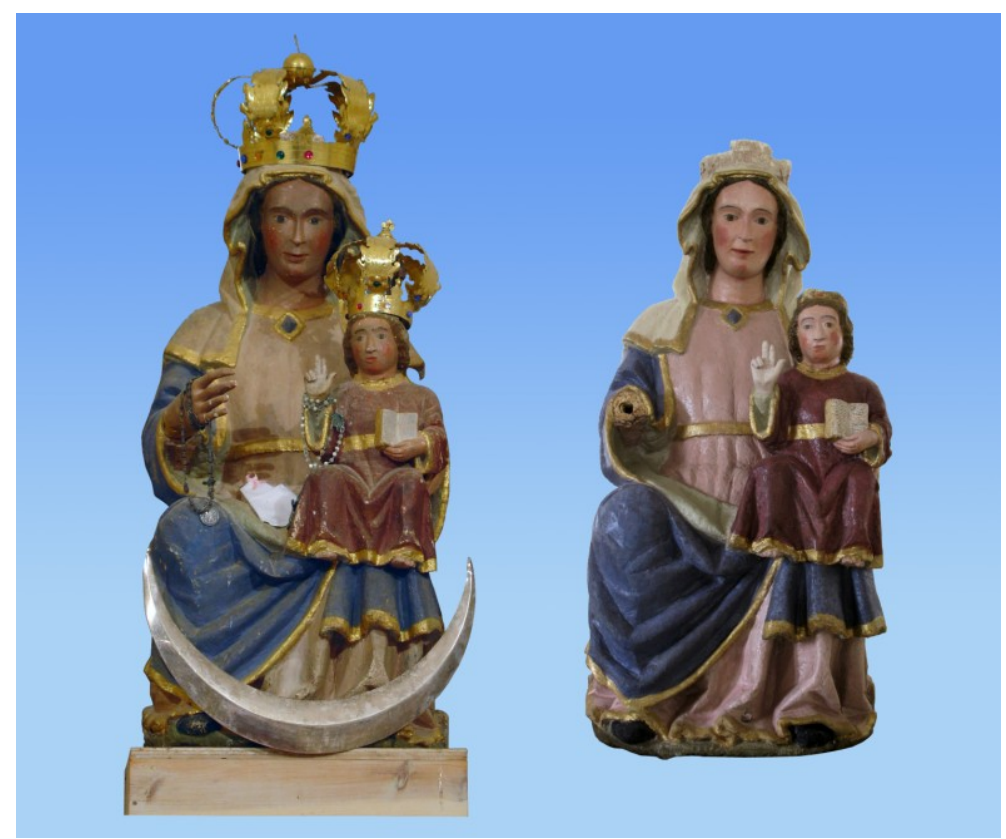

Figura 8. Virgen del Barrio (Rioseco de Soria), antes y después de la restauración realizada por el Proyecto Cultural Soria Románica (2009) 
36. De gran interés antropológico es la biografía reciente de la Virgen del Barrio (Rioseco de Soria $)^{17}$. De la ermita homónima donde se asentaba fue robada hace algunos años. El enorme peso de la imagen (recordamos que es pétrea) motivó que los ladrones desistieran de su labor a medio camino y la dejasen tirada en una acequia, donde la descubrió un vecino. Asustado, el vecindario decidió custodiarla en la parroquia, no sin antes encargar una "reproducción" (de factura no profesional) que actualmente preside el retablito mayor de la citada ermita. En cuanto réplica, representa formalmente, pero no sustituye devocionalmente. Una obviedad, pero que sirve eficazmente para ilustrar las reflexiones que estas páginas abordan.

37. [Figura 9] Singular, desde un punto de vista formal, es el caso de la Virgen de la Asunción de Tajahuerce. Inusual por sus grandes dimensiones (casi un metro de altura), mantiene a un Niño singularmente plano, más cercano a un relieve que a una talla en bulto, pegado al cuerpo, aunque no estamos ni ante el tradicional caso de que ambas figuras sean de una sola pieza, ni ante la presencia del consabido clavo de forja que una dos distintas, sino mediante un original procedimiento: un cajeado practicado sobre el propio regazo de la Virgen, en eje con su propio cuerpo, que acoge el cuerpo del Niño.

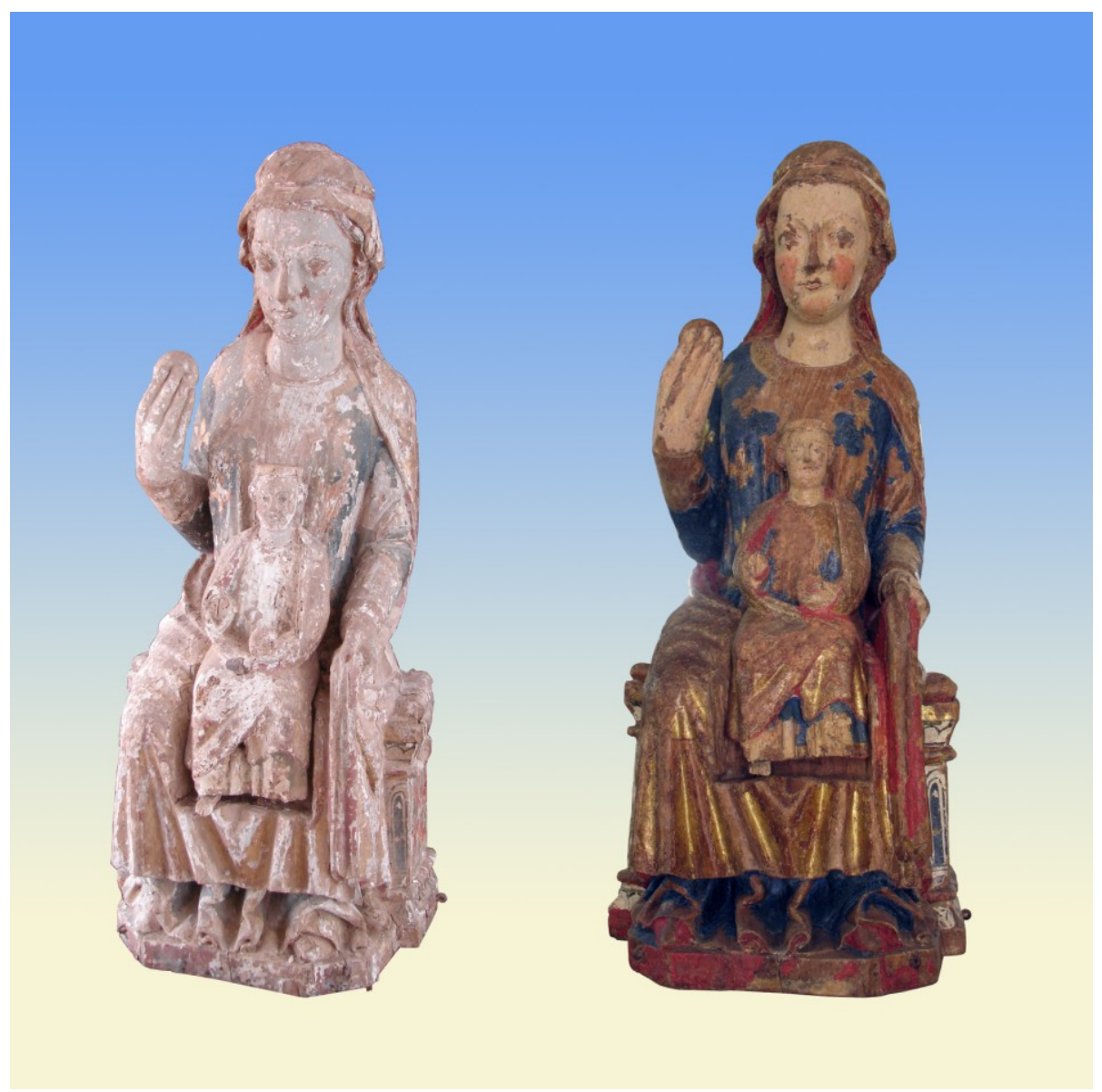

Figura 9. Virgen de la Asunción (Tajahuerce), antes y después de la restauración realizada por el Proyecto Cultural Soria Románica (2009)

38. [Figura 10] Desconocemos el motivo por el cual se llevó a cabo esta práctica, si bien es cierto que se ejecutó sobre la pieza con la policromía que conserva en la actualidad ya realizada. Pudo ocurrir que si la imagen fue vestida el volumen del Niño sobresaliera excesivamente, con lo que se 
retranqueó sobre la Virgen, o que sufriera esta modificación al intentar adaptarla a la hornacina exterior en la que estuvo expuesta durante mucho tiempo. Es el único ejemplo que conocemos en la provincia de Soria, tan abundante en Vírgenes medievales, en que se haya empleado tal solución. Las características de estilo de ambas piezas las hacen contemporáneas y formando parte del mismo conjunto, pero la disposición de las manos de la Madre permite deducir que nunca lo sostuvo con sus brazos.

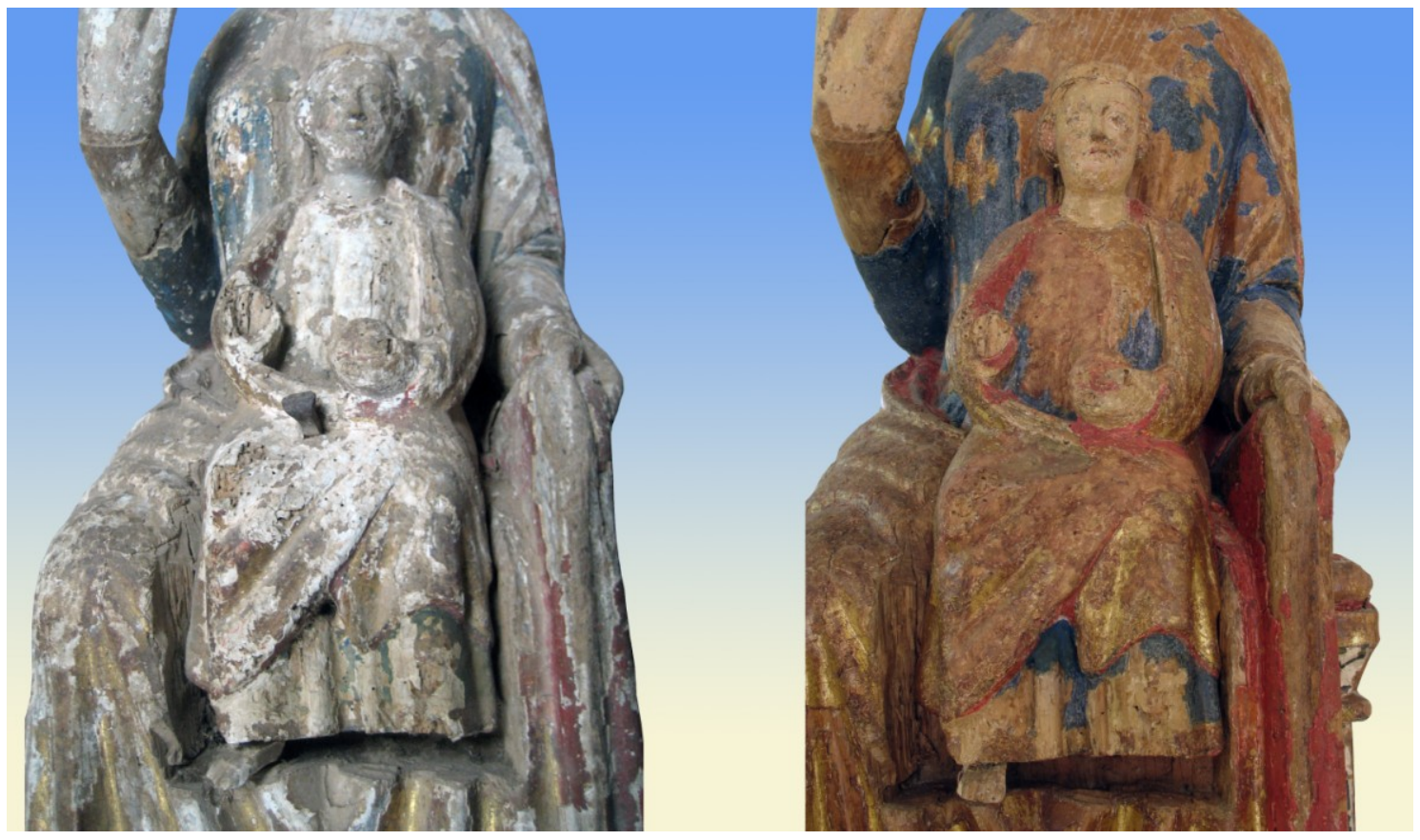

Figura 10. Curioso cajeado realizado para asentar al Niño en la Virgen de la Asunción, antes y después de la restauración

39. En resumen, queríamos reforzar y reivindicar el carácter necesariamente contextual que ha de tener todo proceso de conservación y de restauración de bienes muebles. La mera pieza en sí misma, desgajada de su medio, es similar a lo que para la arqueología supone un objeto aislado, sin estratigrafía, sin lugar de procedencia y sin datos que lo inserten en un campo de significación. Así como en el campo arqueológico hay métodos que hoy serían implanteables, propios de estadios ya pasados, no parece que la situación sea tan halagüeña en las intervenciones sobre bienes muebles. Es un deber documentar todos los registros de información posibles que nos aporten datos sobre la pieza, los propiamente técnicos (catas, análisis...), y necesariamente también los corpora documentales, orales y devocionales, porque, como decíamos, y recordamos aquí, dicha pieza además de un bien mueble es un referente devocional, esto es, además de un objeto es cuerpo vivo, y pasar de esta última categoría a la primera es algo que en ningún caso debe decidir unilateralmente quien posee, promueve o restaura una pieza con valencia devocional. Además de los estudios previos comentados, es necesaria la comunicación entre esta figura que actúa sobre una pieza puntualmente, pero a veces de manera irreversible, y la difusa del "pueblo" que la usufructúa. Si no, permítasenos la expresión, es caer en una especie de "restauracionismo ilustrado"18, y esta "metodología", ya sabemos, ha destruido muchas capas de información en el pasado, y lo sigue haciendo en el presente, aun sin llegar a tocar la pieza con el bisturí. El objetivo último de este artículo, más allá del necesario y sabido cuidado que hay que tener con las modificaciones históricas impresas en las piezas, es apostar por su mantenimiento en su contexto de uso, que le otorga un valor añadido a unas y a otro. Con ello, volviendo al principio, valié más essi pueblo qe la avié vezina, y también la propia talla, añadimos. El éxodo rural no sólo despobló, y despuebla, de personas los pueblos castellanos y leoneses, como los aquí tratados. También se fue llevando, y se lleva, el vecindario de madera. 


\section{Notas}

$\left(^{*}\right)$ El Proyecto Cultural Soria Románica es un plan de conservación, difusión y divulgación del Románico de la provincia de Soria que se desarrolla entre 2007 y 2010. La Junta de Castilla y León promueve y financia este proyecto, gestionado por la Fundación Duques de Soria, con la colaboración del Obispado de Osma-Soria, en virtud del convenio firmado por las tres instituciones. Más información en www.soriaromanica.es [Todas las fotografías que ilustran estas páginas son inéditas, y propiedad de Soria Románica. Su montaje lo ha realizado Luis Miguel Sanz, delineante del Proyecto].

[1] Damos por buenas las conclusiones en torno a las definiciones y distinciones terminológicas entre "policromía", "repolicromía", "repinte" y "reintegración” a las que llegó el Grupo Latino de Escultura Policromada, expuestas en Ruiz de Arcaute 2009: 74-76.

[2] En la misma línea, reflexiona Gabriela Siracusano (2009) en el reciente Congreso del Grupo Español de Conservación que tuvo lugar en Cáceres, tomando casos de tres imágenes quinientistas de México, Bolivia y Colombia a las que la tradición considera creadas sin mediación de mano humana.

[3] La de Lagunas en la ermita del mismo nombre (Villálvaro); igual ocurre con la Virgen del Val (Pedro), residente en su ermita homónima hasta que se trasladó hace poco tiempo por medidas de seguridad, siendo el mismo caso que la riosequeña Virgen del Barrio. Desconocemos la procedencia original de la Virgen de las Alcubillas de Alcozar. Al conservarse otra talla similar bajo la advocación de la Virgen del Vallejo (antigua parroquia, actualmente ermita), quizá la de Alcubillas perteneciese a otra de las ermitas alcozareñas. Finalmente, la Virgen de Tajahuerce, hasta su recentísimo traslado al Museo de la Concatedral de San Pedro (Soria) una vez restaurada por el Proyecto Cultural Soria Románica, se conservaba en la parroquia de la localidad, advocadas ambas a Nuestra Señora de la Asunción. Aunque sea la imagen que más se separa de este conjunto tan homogéneo, su interés formal, como se verá más abajo, justifica traerla a colación.

[4] Diestro Ortega 2009: 395-397; Hernández Álvaro 2009: 392-394. Ninguna se estudia en la Enciclopedia del Románico de Castilla y León. Soria (2002. Aguilar de Campoo).

[5] Sin perjuicio de que esta afirmación pueda trasladarse a otros contextos territoriales similares, algo que el sentido común permite presuponer.

[6] 1578, marzo, 10 [pone 1568 por error]. AHDB, Libro 548/7, f. 152r. Entendemos que esta cita a Nuestra Señora se refiere a la imagen de la Virgen del Rosario, puesto que la de Lagunas debía seguir in situ, ya que la ermita continuaba con culto (como "hermita" se la cita en la documentación en 1529. AHDB, Libro 548/7, f. 50v). Todavía a finales del siglo XVII continuaría allí la imagen, puesto que se "compuso" el retablo que estaba en la ermita, cuya imagen central había de ser la Virgen de Lagunas (1698, junio, 18. AHDB, Libro 548/8, s.f.).

[7] 1612, día de la Expectación de Nuestra Señora. AHDB, Libro 548/7, f. 216r-v. En Villálvaro consta una Cofradía de Nuestra Señora del Rosario, fundada en la iglesia parroquial, al menos desde 1655 (AHDB, Libro 525/10).

[8] Ponz 1947: 1.226 (cit. en Vega 1994: 250).

[9] Villegas 1635: 430-431 (cit. en Vega 1994: 249).

[10] 1756, mayo, 6. AHDB, Libro 45/11, f. 139r.

[12] 1768, septiembre, 27. AHDB, Libro 352/13, f. 88r.

[12] Actualmente, restaurándose en el Centro de Conservación y Restauración de Bienes Culturales de Castilla y León (Simancas). 
[13] 1516, abril, 21. AHDB, Libro 548/7, f. 10v. Por lo general, las cuentas de los libros de fábrica recogen ingresos y gastos realizados en los dos últimos años, así que seguramente esta repolicromía hay que datarla entre 1514-1515. La documentación referente a la ermita no figura entre los libros parroquiales de Villálvaro, sino en los del vecino pueblo de Zayas de Báscones. Entre ambos comparten la devoción a la Virgen de Lagunas, sita actualmente en el término municipal del primer pueblo.

[14] La fanega de trigo oscilaba los años inmediatamente anteriores y posteriores a 1516 entre 150 y 120 maravedises, según los mismos asientos del libro de fábrica (1516, abril, 21. AHDB, Libro 548/7, f. 10v, y 1518, noviembre, 24. AHDB, Libro 548/7, f. 14r, respectivamente).

[15] Dicha ceremonia fue presidida por las Cruces Parroquiales y las imágenes de la Virgen de cada uno de los pueblos participantes. Dado que muchos de ellos conservan la devoción a sus tallas medievales, el resultado fue una espectacular concentración de imágenes en la villa sanestebeña, un auténtico catálogo de piezas, en su mayor parte, de los siglos XIII-XV. Las 44 localidades implicadas fueron: Alcoba de la Torre, Alcozar, Alcubilla de Avellaneda, Alcubilla del Marqués, Aldea de San Esteban, Atauta, Berzosa, Bocigas de Perales, Castillejo de Robledo, Cenegro, Cuevas de Ayllón, Fuencaliente del Burgo, Fuentecambrón, Fuentearmegil, Hoz de Abajo, Hoz de Arriba, Inés, Langa de Duero, Liceras, Ligos, Matanza de Soria, Miño de San Esteban, Montejo de Tiermes, Morcuera, Noviales, Olmillos, Pedraja de San Esteban, Peñalba de San Esteban, Pedro, Piquera de San Esteban, Quintanilla de Tres Barrios, Quintanas Rubias de Abajo, Quintanas Rubias de Arriba, Robollosa de Pedro, Rejas de San Esteban, San Esteban de Gormaz, Soto de San Esteban, Torraño, Torremocha de Ayllón, Torresuso, Valdanzo, Valdanzuelo, Velilla de San Esteban, Villálvaro, Zayas de Báscones, Zayas de Torre y Zayuelas (Se editó un DVD del evento, realizado por la empresa Burcode, Valladolid, 2009).

[16] Un artículo esclarecedor: Martínez Martínez 2008.

[17] Los avatares históricos de la talla, por la documentación consultada en los Libros de Fábrica se recogen en el citado artículo de Diestro Ortega 2009.

[18] Es decir, restaurar según criterios estrictamente historicistas o siguiendo el canon de la historia del Arte, sin tener en cuenta, o directamente despreciando, lo que las imágenes significan para las comunidades que las poseen.

Ya en pruebas este artículo, hemos podido leer, recién publicado, un trabajo interesante por la propuesta restauradora, su ejecución, y la vinculación con los problemas que se plantean en estas páginas, principalmente por la naturaleza de la pieza (una Virgen gótica) y el devocional, que creemos conveniente citar, aunque no hayamos podido integrarlo en la reflexión (Martín García y Gómez González 2010).

\section{Bibliografía}

DIESTRO ORTEGA, Francisca (2009). "Virgen del Barrio", en Catálogo Las Edades del Hombre. Paisaje interior [Soria. Concatedral de San Pedro] Soria: Gráficas Varona, 395-397.

ESTERAS MARTÍNEZ, José Ángel y LORENZO ARRIBAS, Josemi (2009). "Elementos románicos repintados. Planteamiento de una cuestión incómoda", en Ge-conservación. Publicación digital hispano-lusa de conservación y restauración, $\mathrm{n}^{\mathrm{o}}$ 0, 2009, 117-131 [http://ge-iic.com/revista/volumen]

HERNÁNDEZ ÁLVARO, Ana Rosa (1984). La imaginería medieval en la provincia de Soria. Soria: Centro de Estudios Sorianos.

HERNÁNDEZ ÁLVARO, Ana Rosa (2009). "Virgen de la Manzana", en Catálogo Las Edades del Hombre. Paisaje interior [Soria. Concatedral de San Pedro] Soria: Gráficas Varona, 392-394. 
MARTÍN GARCÍA, Juan Carlos y GÓMEZ GONZÁLEZ, Cristina (2010). "La recuperación de la imagen gótica de Nuestra Señora de Carejas: la conservación y restauración, el culto y la devoción”, en VI Congreso Internacional 'Restaurar la memoria'. La gestión del Patrimonio hacia un planteamiento sostenible [AR\&PA, 31 octubre-2 noviembre de 2008. Valladolid]. Salamanca: Junta de Castilla y León, Tomo II, 51-61.

MARTÍNEZ MARTÍNEZ, María José (2008). "Imaginería románica: una manifestación de la espiritualidad medieval”, Biblioteca. Estudio e investigación ['El Medievo en el Duero Oriental. Historia y Arte románico'], 23, 317-343.

ORTEGO FRÍAS, Teógenes (1958): "La ermita Hispano-visigoda de la Virgen del Val en Pedro (Soria)", Archivo Español de Arqueología, 21, 222-230

PONZ, Antonio (1947 [1772]). Viaje de España, o Cartas en que se da noticia de las cosas más apreciables, y dignas de saberse que hay en ella. Madrid: M. Aguilar.

RUIZ DE ARCAUTE MARTÍNEZ, Emilio (2009). “Aportaciones a la teoría de la restauración”, en IV Congreso del Grupo Español del IIC. La restauración en el siglo XXI. Función, estética e imagen [Cáceres, 25, 26 y 27 de noviembre de 2009]. Cáceres, 69-78.

SIRACUSANO, Gabriela (2009). "Entre ciencia y devoción. Reflexiones teóricas e históricas sobre la conservación de imágenes devocionales", en IV Congreso del Grupo Español del IIC. La restauración en el siglo XXI. Función, estética e imagen [Cáceres, 25, 26 y 27 de noviembre de 2009]. Cáceres, 241-248.

VEGA, Jesusa (1994). "Irracionalidad popular en el arte figurativo español del siglo XVIII", en Anales de literatura española, 10, 237-273.

VILLAR MOVELLÁN, Alberto (1989). "Santos travestidos: imágenes condenadas", en Cuadernos de arte e iconografía, 2/4, (Actas del Primer Coloquio de Iconografía), pags. 183-194.

VILLEGAS, Bernardino de (1635). La esposa de Christo, instruida con la vida de Santa Lutgarda. Murcia: Juan Fernández Fuentes.

\section{Archivos consultados}

Archivo Histórico Diocesano de El Burgo de Osma. Libros parroquiales y de cofradías de las parroquias de Andaluz, Alcozar, Pedro, Rioseco de Soria, Villálvaro y Zayas de Báscones. [Las tallas de los pueblos cuya documentación de archivo se ha consultado y no aparecen referencias en el artículo es por no estar registradas las operaciones realizadas sobre ellas].

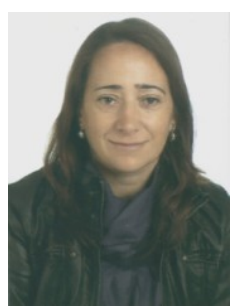

Francisca Diestro Ortega

frandior2@hotmail.com

Restauradora del Proyecto Cultural Soria Románica, y del Taller Diocesano de Restauración de la Diócesis de Osma-Soria. Licenciada en Bellas Artes por la Universidad del País Vasco. Autora de diversos artículos sobre restauración y participante en conferencias sobre Patrimonio mueble diocesano. 


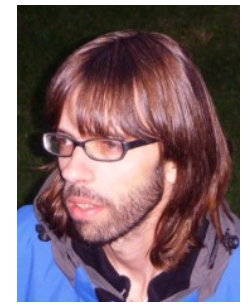

Josemi Lorenzo Arribas

josemi@soriaromanica.es

Historiador del Proyecto Cultural Soria Románica. Doctor en Historia Medieval por la Universidad Complutense, es autor de cinco libros sobre distintos aspectos de la Edad Media, y más de sesenta artículos de diversos temas históricos, etnográficos y musicológicos.

Artículo recibido el 30/03/2010.

Artículo aceptado el 25/06/2010 